\title{
The Influence of Parent Support and Learning Motivation Towards The Achievement of Islamic Education Learning in The Pandemic Time Covid-19
}

\author{
Supriyadi ${ }^{1}$, Qowaid ${ }^{2}$, Hayadin $^{3}$, Murtadho $^{4}$, Lisa'diyah Ma'rifataini ${ }^{5}$, Ayu Nurul Amalia ${ }^{6}$, \\ Syafwandi ${ }^{7}$, Lebeng ${ }^{8}$, Octaviola ${ }^{9}$, M. Edi Sulaksono ${ }^{10}$, Zaharuddin $^{11}$, Sri Wahyuningsih ${ }^{12}$ \\ \{ $\underline{\text { supriyadiesbe@gmail.com }}{ }^{1}$, qowaidbmasyhuri@gmail.com ${ }^{2}$, , hayadin006@gmail.com ${ }^{3}$, \\ ,tadho25@gmail.com ${ }^{4}$, lisa.litbang@gmail.com ${ }^{5}$, ayunurulamalia.ana@gmail.com ${ }^{6}$, \\ syafwandi@menarasiswa.ac.id ${ }^{7}, 1$ bheru1@gmail.com ${ }^{8}$, oktav0116@gmail.com ${ }^{9}$, \\ medisulaksono@gmail.com ${ }^{10}$, zaharuddin111264@gmail.com ${ }^{11}$, yuniwahyuningsih33@yahoo.com ${ }^{12}$ \}
}

Panca Sakti University Bekasi ${ }^{1}$, IAI Nasional Laa Roiba ${ }^{2}$, The Center of Religius Education R\&D Ministry of Religios Affair ${ }^{3}$, The Center of Religius Education R\&D Ministry of Religios Affair ${ }^{4}$, The Center of Religius Education R\&D Ministry of Religios Affair ${ }^{5}$, Panca Sakti University Bekasi ${ }^{6}$, STIA Menara Siswa ${ }^{7}$, Madrasah Tsanawiyah Negeri 7 East Jakarta ${ }^{8}$, Madrasah Tsanawiyah Negeri 7 East Jakarta $^{9}$, Islamic education Ministry of Religious Affairs office Administrative District AThousand Islands DKI Jakarta Province ${ }^{10}$, STIMA IMMI ${ }^{11,12}$

\begin{abstract}
The coronavirus or better known as the COVID-19 is a worldwide problem. This paper aims to reveal the effect of parental support and learning motivation on distance learning on learning achievement in Islamic religious education, the newness of this research was carried out in the conditions of the Covid-19 pandemic. This study used a survey method with a population of all students at MTsN 7 East Jakarta. The research sample was 261 respondents with a random sampling technique. The research data were obtained through valid and reliable instruments. Data analysis using multiple regression analysis.It is concluded that there is an effect of parental support on learning achievement, there is an influence of learning motivation on learning achievement, and there is an effect of parental support and learning motivation simultaneously on the learning achievement of Islamic religious education. The coefficient of determination of the effect of parental support and learning motivation together on learning achievement is $85 \%$.
\end{abstract}

Keywords: Parental Support, Learning Motivation, Learning Achievement of Islamic Education

\section{Introduction}

The emergence of the coronavirus or better known as COVID-19 is a worldwide problem. In Indonesia, the spread of COVID-19 was first discovered on March 2, 2020, this was conveyed directly by the President of the Republic of Indonesia Joko Widodo (Nuraini, 2020 ), and currently, it has infected 23,165 people with a death toll of 1,418 people, and the number of patients who recovered 5,877 people (covid19.go.id, 2020).

The government has made various efforts to break the chain of the spread of the coronavirus, one of the government's efforts to issue government regulation (PP) Number 21 of 2020 concerning Large-Scale Social Restrictions in the Context of Accelerated Handling of Covid-19 which results in restrictions on various activities including schools. This government 
regulation was followed by the issuance of the Minister of Education and Culture Circular Number 36962 / MPK.A / HK / 2020 concerning online learning and working from home in order to prevent the spread of Corona Virus Disease (COVID-19). The Ministry of Religion issued a Decree of the Director-General of Islamic Education Number 2791 of 2020 concerning Emergency Curriculum Guidelines for Madrasas. Learning in Madrasas has also been affected by Covid-19. This policy certainly has an impact not only on the teacher and student relations during BDR but also on the importance of optimizing the role of parents in implementing BDR.

The role of parents in accompanying children's success while studying at home is very central, in relation to this WHO, (2020) released various guidelines for parents in accompanying their children during this pandemic which includes parenting tips to be more positive and constructive in accompanying them. children during activities at home. Prabhawani (2016) states that the implementation of education is the responsibility of parents and the surrounding community, not only the responsibility of educational institutions.

Prabhawani (2016) states that the implementation of education is the responsibility of parents and the surrounding community, not only the responsibility of educational institutions.

Lestari, (2012) states that the family is seen from its function, namely having a duty and function of care, emotional and material support, and fulfillment of certain roles.

The learning process, which is usually done face-to-face, has now been completely transformed into an online learning system. This has indirectly caused panic among various parties related to children's education. In other words, this period can also be called a time full of uncertainty for some children.

This has an effect on a significant decrease in learning motivation. The boredom of students in facing learning methods that are limited and seem monotonous, coupled with the various tasks and homework they have to do, adds to the fatigue of students in carrying out the online learning process.

From the results of the researchers' observations when conducting preliminary observations, the results of interviews with several teachers said that approximately $40 \%$ of students experienced a decrease in learning motivation, this decrease in learning motivation was quite a factor.

Strategic steps are needed in order to maintain the learning motivation of students to continue the learning process during this crisis period. Educational institutions have taken various anticipatory actions to continue the education system to ensure children's rights. However, the movement of educational institutions is very limited due to limited direct contact and supervision of teachers as educators to their students. So, indirectly the role of the Teacher slowly moved to the parents. Parents should make various efforts in the process of children's education during the COVID-19 period. Parents are the closest people around students, so parents need to make various efforts to support children in their learning period.

Internal and external factors are variables that can affect the learning achievement of students in Islamic religious education. There are still many learning achievements in Islamic religious education subjects that have values below the minimum completeness criteria (KKM) during the Covid-19 pandemic, namely as many as $54 \%$ of students

To optimize learning achievement in Islamic religious education subjects, knowledge of the influence of a factor and the interactions between factors is required. This study aims to determine the factors of parental support and learning motivation on student achievement during the Covid-19 pandemic. Many studies discuss support and motivation for learning achievement in Islamic religious education, the newness of this research lies in the conditions and situations, namely when the Covid-19 pandemic occurs which is also a world problem. 
Islamic religious education according to Bawani (1993) Religious education can be defined as an effort to actualize the perfect qualities that have been bestowed by Allah SWT to humans, these efforts are carried out without any strings attached except for solely worshiping Allah SWT.

Islamic religious education experts (2005) have tried to formulate the notion of Islamic education, among these very varied boundaries are: Al-Syaibany argues that Islamic religious education is the process of changing the individual behavior of students in personal life, society, and the surrounding environment. This process is carried out by means of education and teaching as human and professional activities among the many human professions in society.

Religious education is education that provides knowledge and shapes the attitudes, personalities, and skills of students in practicing their religious teachings, which is carried out at least through subjects in all channels, levels, and types of education. (Regulation of the Minister of Religion of the Republic of Indonesia Number 16 of 2010 concerning Management of Religious Education in Schools) Article 1 paragraph 1.

Muhaimin (2008) explains that Islamic education has two main points, namely (1) Islamic education is an educational activity organized with the desire and intention to embody Islamic teachings and values, and (2) Islamic education is an education system developed from and imbued with or imbued with Islamic teachings and values.

Langgulung (1998) Islamic education is a process of preparing young people to fill roles, transfer knowledge, and Islamic values that are aligned with human functions to do good in the world and reap the results in the hereafter.

\section{Research Methods}

The research method used in this research is a survey method. The population of this study was all students at Madrasah Tsanawiyah Negeri 7 East Jakarta totaling 617 students. The sampling technique used was random sampling. Data collection in the form of scores was taken using the instrument of parental support and learning motivation instruments in the form of an attitude scale instrument. The learning achievement score is taken from the average value of Islamic religious education subjects in the even semester report cards for the 20192020 school year. The parental support instrument is valid and has an Alpha reliability of 0.831 . The learning motivation instrument is also valid and reliable with the Alpha reliability of the I dimension of 0.832 and the II dimension of 0.762 . The data analysis technique used multiple regression analysis where parental support was the independent variable (X1) and learning motivation (X2) for the dependent variable (Y), namely the learning achievement of Islamic religious education. This study aims to reveal 1) Is there an effect of parental support on learning achievement of Islamic religious education during the Covid-19 pandemic ?; 2) Is there an effect of learning motivation on learning achievement during the Covid-19 pandemic ?; 3) Is there an effect of parental support and learning motivation simultaneously on students' learning achievement during the Covid-19 pandemic? Analysis of research data was carried out by first describing, then conducting a prerequisite test by testing the normality and homogeneity of the data, after obtaining normal and homogeneous data followed by hypothesis testing with regression analysis either partially or simultaneously. 


\section{Research Result}

The data description for the variable score of Parental Support, Learning Motivation, and Learning Achievement is presented in the following table:

Table 1. Deskripsi Skor Variabel

\begin{tabular}{|l|l|r|r|r|}
\hline \multicolumn{2}{|l|}{} & $\begin{array}{c}\text { Dukungan } \\
\text { Orang Tua }\end{array}$ & $\begin{array}{c}\text { Motivasi } \\
\text { Belajar }\end{array}$ & $\begin{array}{c}\text { Prestasi } \\
\text { Belajar }\end{array}$ \\
\hline \multirow{2}{*}{$\mathrm{N}$} & Valid & 261 & 261 & 261 \\
\cline { 2 - 5 } & Missing & 0 & 0 & 0 \\
\hline Mean & 59.4176 & 57.1456 & 82.4061 \\
\hline Median & 60 & 57 & 83 \\
\hline Mode & 60 & 58 & 83 \\
\hline Std. Deviation & 5.16701 & 5.21922 & 5.27802 \\
\hline Minimum & 48 & 46 & 71 \\
\hline Maximum & 73 & 71 & 96 \\
\hline
\end{tabular}

From the table above, it can be described for the parent support variable (X1), the mean value is 59.4176 , the median 60 , the mode 60 , the standard deviation is 5.16701 , the lowest score is 48 and the highest score is 73 . The learning motivation variable (X2) gets the mean value average (mean) 57.1456, median 57, mode 58, standard deviation 5.21922 lowest score 46, and highest score 71 . The learning achievement variable (Y) obtained an average value (mean) 82.4061, median 83, mode 83, standard deviation 5.27802 lowest score 71, and the highest score was 90.

The prerequisite test in this study tests the normality and homogeneity of the research data, the following are the prerequisite tests for the normality of the data for the three variables as follows:

Table 2. Uji Prasyarat Normalitas Data

One-Sample Kolmogorov-Smirnov Test

\begin{tabular}{|c|c|c|c|c|}
\hline & & $\begin{array}{l}\text { Dukungan } \\
\text { Orang Tua }\end{array}$ & $\begin{array}{l}\text { Motivasi } \\
\text { Belajar }\end{array}$ & $\begin{array}{l}\text { Prestasi } \\
\text { Belajar }\end{array}$ \\
\hline \multicolumn{2}{|l|}{$\mathrm{N}$} & 261 & 261 & 261 \\
\hline \multirow{2}{*}{$\begin{array}{l}\text { Normal } \\
\text { Parametersa }^{, b}\end{array}$} & Mean & 59.4176 & 57.1456 & 82.4061 \\
\hline & Std. Deviation & 5.16701 & 5.21922 & 5.27802 \\
\hline \multirow{3}{*}{$\begin{array}{l}\text { Most Extreme } \\
\text { Differences }\end{array}$} & Absolute & 0.068 & 0.067 & 0.072 \\
\hline & Positive & 0.068 & 0.067 & 0.072 \\
\hline & Negative & -0.059 & -0.06 & -0.059 \\
\hline
\end{tabular}




\begin{tabular}{|l|r|r|r|}
\hline Kolmogorov-Smirnov Z & 1.101 & 1.085 & 1.164 \\
\hline Asymp. Sig. (2-tailed) & 0.177 & 0.19 & 0.133 \\
\hline
\end{tabular}

From the table above the Asymp score. Sig. (2-tailed) for the parental support variable, pvalue $=0.177>0.05$, thus the parent support variable is normally distributed. The learning motivation variable obtained $\mathrm{p}$-value $=0.190>0.05$, thus the learning motivation variable was normally distributed and the learning achievement variable obtained $p$-value $=0.133>0.05$, thus the learning achievement variable was normally distributed.

The homogeneity test in this study obtained the following data:

Table 3. Uji Prasyarat Uji Homogenitas

Levene's Test of Equality of Error Variances

Dependent Variable: Skor

\begin{tabular}{|c|c|c|c|}
\hline$F$ & $\mathrm{df1}$ & $\mathrm{df} 2$ & Sig. \\
\hline .028 & 2 & 780 & .972 \\
\hline
\end{tabular}

From the table above, the Levene test results show a sig of $0.972>0.05$, thus the three data groups come from a homogeneous group.

1) Multiple Linear Equations and Significance Test of the Coefficient of Regression Equations

Table 4. Coefficients

Coefficients $^{\mathrm{a}}$

\begin{tabular}{|c|c|c|c|c|c|c|}
\hline & \multirow[t]{2}{*}{ Model } & \multicolumn{2}{|c|}{$\begin{array}{l}\text { Unstandardized } \\
\text { Coefficients }\end{array}$} & \multirow{2}{*}{$\begin{array}{c}\begin{array}{c}\text { Standardized } \\
\text { Coefficients }\end{array} \\
\text { Beta }\end{array}$} & \multirow[t]{2}{*}{$\mathrm{t}$} & \multirow[t]{2}{*}{ Sig. } \\
\hline & & B & Std. Error & & & \\
\hline \multirow{3}{*}{1} & (Constant) & 31.272 & 1.651 & & 18.94 & 0 \\
\hline & Dukungan Orang Tua & -0.067 & 0.029 & -0.065 & -2.332 & 0.02 \\
\hline & Motivasi Belajar & 0.964 & 0.028 & 0.954 & 34.013 & 0 \\
\hline
\end{tabular}

\section{a. Dependent Variable: Prestasi Belajar}

From the table above, it is obtained the constant $\mathrm{b} 0=31,272$, the regression coefficient $\mathrm{b} 1=$ 0.067 and $\mathrm{b} 2=0.964$. So the multiple linear regression equation is $\hat{\mathrm{Y}}=31,272+(-0.067) \mathrm{X} 1$ $+0.964 X 2$.

Hypothesis: $\mathrm{H} 0: \beta 1 \leq \mathrm{vs} \mathrm{H} 1: \beta 1>0$ and $\mathrm{H} 0: \beta 2 \leq \mathrm{vs} \mathrm{H} 1: \beta 2>0$.

From the results of the analysis above shows the statistical price for the variable coefficient $\mathrm{X} 1$, namely tit $=-2.332$ and $\mathrm{p}$-value $=0.02 / 2=0.01<0.05$ (right side test), or H0 is rejected, 
which means that parental support during distance learning has an effect. positive towards student learning achievement.

Furthermore, the statistical price for the variable coefficient X2 is thit $=34.013$ and $\mathrm{p}$-value $=$ $0.00 / 2=0.00<0.05$ (right side test), or H0 is rejected, which means that learning motivation has a positive effect on student learning achievement.

1) Significance Test of Multiple Regression Equations

Table 5. Anova

ANOVA $^{\mathrm{a}}$

\begin{tabular}{|c|c|c|c|c|c|c|}
\hline & Model & $\begin{array}{c}\text { Sum of } \\
\text { Squares }\end{array}$ & df & $\begin{array}{l}\text { Mean } \\
\text { Square }\end{array}$ & $\mathrm{F}$ & Sig. \\
\hline \multirow{3}{*}{1} & Regression & 6155.756 & 2 & 3077.878 & 730.405 & $.000^{\prime}$ \\
\hline & Residual & 1087.194 & 258 & 4.214 & & \\
\hline & Total & 7242.95 & 260 & & & \\
\hline
\end{tabular}

a. Dependent Variable: Prestasi Belajar

b. Predictors: (Constant), Motivasi Belajar, Dukungan Orang Tua

Hypothesis:

$\mathrm{H}_{0}: \beta_{1}=\beta_{2}$ or $\mathrm{H}_{0}: \beta_{1}-\beta_{2}=0$

$\mathrm{H}_{0}: \beta_{1} \neq \beta_{2}$ or $\mathrm{H}_{0}: \beta_{1}-\beta_{2}=0$

From the analysis results summarized in the ANOVA table above, it is obtained that Fhit $=$ 730.405 , and $\mathrm{p}$-value $=0.000<0.05$, or this means that $\mathrm{H} 0$ is rejected. This means that there is a linear influence on the variable parental support and learning motivation with the learning achievement of students in distance learning during the Covid-19 pandemic. This also means that there is a joint (simultaneous) influence on parental support and learning motivation on learning achievement in distance learning during the Covid-19 period.

1) Significance Test of Multiple Correlation Coefficient

Table 6. Model Summary

Model Summary

\begin{tabular}{|c|c|c|c|c|c|c|c|c|c|}
\hline \multirow{2}{*}{ Model } & \multirow[b]{2}{*}{$\mathrm{R}$} & \multirow{2}{*}{ R Square } & \multirow{2}{*}{$\begin{array}{l}\text { Adjusted } \\
\text { R Square }\end{array}$} & \multirow{2}{*}{$\begin{array}{l}\text { Std. Error } \\
\text { of the } \\
\text { Estimate }\end{array}$} & \multicolumn{3}{|c|}{ Change Statistics } & \multicolumn{2}{|c|}{ Change Statistics } \\
\hline & & & & & $\begin{array}{l}\text { R Square } \\
\text { Change }\end{array}$ & F Change & df1 & df2 & $\begin{array}{c}\text { Sig. F } \\
\text { Change }\end{array}$ \\
\hline 1 & $.922^{a}$ & 0.85 & 0.849 & 2.05279 & 0.85 & 730.405 & 2 & $258^{\mathrm{a}}$ & 0 \\
\hline
\end{tabular}

a. Predictors: (Constant), Motivasi Belajar, Dukungan Orang Tua

Hipotesis Statistic:

$\mathrm{H}_{0}: \rho_{\mathrm{y} .12} \leq 0$

$\mathrm{H}_{1}: \rho_{\mathrm{y} .12}>0$

The multiple correlation coefficient significance tests are obtained from the model summary table above. Multiple correlation coefficient $($ Ry. 12$)=0.922$ and Fhit (Fchange) $=730.405$, and $\mathrm{p}$-value $=0.000<0.05$ or $\mathrm{H} 0$ is rejected. Thus, the double correlation coefficient between $\mathrm{X} 1$ and $\mathrm{X} 2$ with $\mathrm{Y}$ is significant or significant, while the coefficient of determination $\mathrm{R}$ Square $=0.850$, which means that $85 \%$ of the learning achievement variable $(\mathrm{Y})$ can be explained by 
parental support (X1) and learning motivation ( X2), so it can be concluded that the effect of parental support and learning motivation together on learning achievement is $85 \%$.

1) Significance Test of Partial Correlation Coefficient

a) a) Correlation between parental support $\left(\mathrm{X}_{1}\right)$ and learning achievement (Y) by controlling for the influence of learning motivation $\left(\mathrm{X}_{2}\right)\left(\mathrm{r}_{\mathrm{y} 1.2}\right)$

Table 7. Correlations Partial

Correlations

\begin{tabular}{|c|c|c|c|c|}
\hline \multicolumn{3}{|c|}{ Control Variables } & Dukungan & Prestasi \\
\hline \multirow{6}{*}{ Motivasi Belajar } & \multirow{3}{*}{ Dukungan Orang Tua } & Correlation & 1 & -0.144 \\
\hline & & Significance (1-tailed) & & 0.01 \\
\hline & & df & 0 & 258 \\
\hline & \multirow{3}{*}{ Prestasi Belajar } & Correlation & -0.144 & 1 \\
\hline & & Significance (1-tailed) & 0.01 & \\
\hline & & df & 258 & 0 \\
\hline
\end{tabular}

From the analysis results in the table above, it is obtained $($ ryl.2) $=-0.144$ and p-value $=0.01<0.05$ or $\mathrm{H}_{0}$ is rejected. Thus, the correlation coefficient between parental support $\left(\mathrm{X}_{1}\right)$ and learning achievement $(\mathrm{Y})$ by controlling for the learning motivation variable $\left(\mathrm{X}_{2}\right)$ is significant.

b) The correlation between learning motivation $\left(\mathrm{X}_{2}\right)$ and learning achievement $(\mathrm{Y})$ by controlling the influence of parental support $\left(\mathrm{X}_{1}\right)\left(\mathrm{r}_{\mathrm{y} 2.1}\right)$

Table 8. Correlations Partial

\section{Correlations}

\begin{tabular}{|c|c|c|c|c|}
\hline \multicolumn{3}{|c|}{ Control Variables } & $\begin{array}{l}\text { Prestasi } \\
\text { Belaiar }\end{array}$ & $\begin{array}{l}\text { Motivasi } \\
\text { Belaiar }\end{array}$ \\
\hline \multirow{6}{*}{ Dukungan Orang Tua } & \multirow{3}{*}{ Prestasi Belajar } & Correlation & 1 & 0.904 \\
\hline & & Significance (1-tailed) & & 0 \\
\hline & & df & 0 & 258 \\
\hline & \multirow{3}{*}{ Motivasi Belajar } & Correlation & 0.904 & 1 \\
\hline & & Significance (1-tailed) & 0 & \\
\hline & & $d f$ & 258 & 0 \\
\hline
\end{tabular}

From the analysis result in the table above, it is obtained $\left(r_{y 2.1}\right)=0.904$ and $p$-value $=$ $0.00<0.05$ or $\mathrm{H}_{0}$ is rejected. Thus, the correlation coefficient between learning 
motivation $\left(\mathrm{X}_{2}\right)$ and learning achievement $(\mathrm{Y})$ by controlling for the parental support variable $\left(\mathrm{X}_{1}\right)$ is significant.

\section{Discussion}

Parental support during distance learning has a positive effect on the learning achievement of students in Islamic religious education. The results of this study are in line with Prabhawani (2016) which states that the implementation of education is the responsibility of parents and the surrounding community, not only the responsibility of educational institutions. Lestari, (2012) states that the family is seen from its function, namely having a duty and function of care, emotional and material support, and fulfillment of certain roles. Learning achievement is a skill developed in a subject, closer to the test scores or numbers given by the teacher. Learning achievement is the ability that someone has achieved in the form of thinking, feeling, and running, achievement is said to be good if it fulfills three scopes, namely: cognitive, affective, and psychomotor, while it is said that achievement is less satisfactory if the individual has not been able to master these targets. From the above understanding, it can be said that learning achievement plays a role in students' abilities related to the teaching and learning process. Student achievement can be seen after being evaluated. The results of the evaluation can be seen from the high or low student achievement (Agustina, 2011).

In addition, the results of this study support the results of research by Kurniati and friends (2020) with the research title "Analysis of the Role of Parents in Accompanying Children during the Covid-19 Pandemic". Kurniati's research results show that the role of parents is very important in creating a distance learning environment safe, comfortable, and conducive with this support can stimulate the brain to capture teacher delivery when distance learning is carried out. Thus the first hypothesis in this study is supported by empirical data.

The learning motivation of students in distance learning has a positive effect on the learning achievement of students in Islamic religious education. The results of this study support David McClelland's theory which reveals that power, affiliation, and achievement are motivations that strongly refer to each individual. McClelland sparked a theory related to the concept of learning where needs are generated from culture and then learned through their environment. McClelland stated that the individual's need to achieve success is closely related to the formation of behavior and its effect on academic achievement. Motivation is very close to oneself, especially students because, with motivation, we will have an enthusiasm for learning (Naomi, 2013). Learning achievement is the foundation of a series of learning processes. Factors that greatly influence learning achievement are motivation, physical condition, intelligence, school environment, teachers, community, family (parents), facilities and infrastructure, curriculum, and others. The most important thing in learning achievement is motivation. Motivation is very important to do and achieve something that can be influenced from outside and from within the individual. Motivation is very important in the learning and teaching process in the world of education or academics (Gunawan, 2014). Thus the second hypothesis of this study is supported by empirical data.

There is a linear influence on the variable parental support and learning motivation with the learning achievement of students in distance learning during the Covid-19 pandemic. This also means that there is a joint (simultaneous) influence on parental support and learning motivation on learning achievement in distance learning during the Covid-19 period. The role of parents in accompanying children's success while studying at home is very central, in relation to this WHO, (2020) released various guidelines for parents in accompanying their children during this pandemic which includes parenting tips to be more positive and 
constructive in accompanying them. children during activities at home. Parents initially played a role in guiding basic attitudes and skills, such as religious education to obey the rules, and for good habituation (Nurlaeni \& Juniarti, 2017), but their role has expanded, namely as a companion to academic education.

\section{Conclusion}

From the results of the research and discussion in this study, it is concluded that:

1. There is an effect of parental support on distance learning which affects the achievement of Islamic religious education during the Covid-19 pandemic

2. There is an effect of learning motivation on distance learning on the achievement of Islamic religious education during the Covid-19 pandemic

3. There is an effect of parental support and learning motivation on distance learning together (simultaneously) on the learning achievement of students during the Covid-19 pandemic.

4. The effect of parental support and learning motivation together on learning achievement is $85 \%$.

\section{Reference}

[1] Akhir, Yaumil Agoes. (1998). "Towards Personal Success with IQ, Social Skills, and Emotional Maturity," One-Day Seminar Papers. Jakarta: Universitas Indonesia.

[2] Alder, Harry. (2001). Boost Your Intelligence, translation Kristina Prianingsih. Jakarta: Erlangga.

[3] Arikunto, S. (2009). Management Research. Jakarta: PT Rieka Cipta.

[4] Atwater. (1993). Expressions of Emotion, The Encyclopedia. New York: Harvard University.

[5] Bloom, Benyamin S. et al. (1981). Taxonomy of Educational Objective: Handbook I. New York: Longman Inc.

[6] Briggs, Leslie J. (1979). Instructional Design Principles and Application. New Jersey: Newelence and Prentice Hall.

[7] Catalina, C. (1992). Learning, third ed. New Jersey: Prentice-Hall International

[8] Goleman, Daniel. (1995). Emotional Intelligence. New York: Scientific

American.

[9] Hasan Langgulung, Pendidikan Islam Menghadapi Abad 21, (Jakarta: Al-Husna, 1988)

[10] Hamalik, Oemar. (1991). A New Approach to Teaching and Learning Strategies

Based on CBSA. Bandung: CV. Sinar Baru.

[11] Iskandar, Mukhtar. (2010). Learning design based on Information and Communication Technology. Jakarta: Gaung Persada Press.

[12] Johana E. Prawitasari. (1995). Know Emotions Through Nonverbal Communication. Yogyakarta: Fakultas Psikologi UGM.

[13] Kadir. (2010). Statistics for Social Sciences Research. Jakarta: PT Rosemata Sampurna.

[14] Kartono, K. (1996). Introduction to Social Research Methodology. Bandung: CV Mandar Maju.

[15] Maslow, A.H.1976. The Farther Reaches of Human Nature. Middlesex: Penguin

[16] Miarso, Yusufhadi. (1989). Monograph of Educational Technology. Jakarta: Dirjen Dikti, Depdikbud.

[17] Munandar 2002, Kreativitas dan keberbakatan, strategi mewujudkan potensi kreatif dan bakat, PT Gramedia utama Jakarta

[18] Muhaimin, Rekonstruksi Pendidikan Islam, (Jakarta: Rajagrafindo Persada), 2008,

[19] National Education Number 20. (2003). Materials Socialization, Depdiknas. 
[20] Rogers C.R 1982, Towards a theory of creativity, Dalam P.E Vernon Creativity England Penguin Books.

[21] Utami Munandar 2009. Pengembangan Kreativitas Anak berbakat. Jakarta Rineka Cipta. 